\title{
Cricket as a Vehicle for Community Cohesion: Building Bridges with British Muslims
}

\begin{abstract}
Purpose - The purpose of this paper is to review practices and research within the social change and community cohesion disciplines, with a view to applying them in the context of British Muslims and cricket. The paper aims to discuss the role of sport, and especially cricket, to help build community cohesion and bring about social change between British Muslims and the wider British society.

Design/Methodology/Approach - This paper uses an inductive and critical approach. Findings - This paper suggests that, the apolitical nature of sport and the popularity of cricket within the South-east Asian British Muslim community can be used as an effective tool to build relationships between British Muslims and the wider British Society. It calls for reflexive thought and action on the part of cricket management to engage in community projects that will enhance the image of cricket as well as genuinely benefitting the society.

Originality/Value - Growth of British Muslims has created a great amount of interest from a marketing perspective. Research into Islamic Marketing and British Muslim consumers are still in its infancy. This paper introduces an under researched area of British Muslims (to date), namely British Muslim sport spectators, and calls for cricket managers and marketers to take an active approach to embarking upon social change.
\end{abstract}

Keywords: Cricket, British Muslims, Social Change

Article Classification: Conceptual paper 


\section{Introduction}

Islam and Muslims have been the subject of countless discussions and debates across many spheres of life ranging from politics, sociology, anthropology and more recently, marketing. The interest in the marketing sphere is not very surprising considering that the British Muslims have a combined spending power of at least $£ 20.5$ billion (Salzman, 2007). Furthermore, a recent report by the Pew Research Centre of Religion and Public Affairs estimated that by 2030, Muslims are expected to make up $8.2 \%$ of the UK population, up from $4.6 \%$ in 2010 . Pew also estimates that the UK will have the largest increase in the number of Muslims in Europe in the next 20 years. This economic, social and cultural benefit of Muslims as consumers underlies the increasing interest in Islamic Marketing both amongst the academic and management circles (Sandikci and Rice, 2011; Temporal, 2011).

Whereas the marketing community views the Muslim population as potential consumers, the wider public image and response to the increasing number of Muslim population has been more controversial in nature. Especially since the events of 9/11 and 7/7 in USA and London respectively, Muslims have been depicted as a threat by some parts of the media and politicians, and the increase in the number of Muslims has been used by the far right to fuel their arguments of a Muslim take-over of the West (Esposito and Lalwani, 2011). As Esposito and Lalwani (2011) argue:

The reality is that there is no takeover, but that there is a danger of intolerance that threatens the very fabric of British and European society. We are not witnessing a clash of civilisations, but a clash of cultures fostered by those who portray Islam as a monolith and see religious and cultural diversity solely as a threat rather than as a potential source of strength and enrichment. The liberal democratic heritage and fabric of our societies must be safeguarded and fear mongering, religious and racial discrimination rejected and marginalised in a future based on facts not fiction.

Muslims and news relating to Muslims were brought into spotlight considerably more in the past decade or so. British newspaper coverage of Muslims increased to over $250 \%$ in the post 9/11 era (Malcolm et al., 2010). However, this increased coverage has tended to focus more towards the negative aspect of incidents and actions performed by those who are Muslims. As Malcolm et al. (2010) found, when those 
who happen to be Muslims engage in violent, repressive, or intolerant activities, it seems to be almost always linked to stereotypes of 'Muslims'. Whittaker (2002) identified four persistent stereotypes of Muslims in the British press as: intolerance, misogyny, violence/cruelty, and strangeness/difference.

As the Western media associate Muslims with the East, Muslims and Islam have become entwined with Orientalistic prejudices. Carrington (2008) claims that the 'Asian Muslim' has become the 'other' which the British liberal democracy must stand against. There are many ongoing debates and discussions about the representation or misrepresentation of Muslims as intolerant, misogynistic, violent and so forth (e.g. Allen, 2010; Ennaji and Sadiqi, 2011). This is beyond the scope of this paper. The focus here is on the issue of 'strangeness' or being seen as the 'other' Being seen as the 'other' is by no means one-dimensional or limited to those who are Muslims. Muslims also in many cases view those who are not Muslims as the 'other' and this is also embedded in cultural stereotypes of what is regarded as the 'Western people'. As Chigas (2003) explains, two parties within a conflict can create demonic images of each other and develop a virtuous self-image. This leads onto dehumanisation and creates a stalemate on both sides.

Ramadan (2010) explains that the idea of distancing oneself from the 'other' (be it a different culture, race or religion) is an unconscious effort to preserve our own identities.

....the other becomes our negative mirror, and the other's difference allows us to define ourselves, to identify ourselves and, basically give us some reassurance.....The other distracts us from ourselves, our ignorance, our fears and our doubts, whilst the presence of the other justifies and explains our suspicions. (Ramadan, 2010: ix)

Social scientists argue that breaking these perceptions of 'us' and 'them' is the starting point in bringing diverse groups together (e.g. Schulenkorf, 2010, Kabir, 2010, Burdsey, 2006). When two parties start to see each other not as strangers but as humans and become familiar with one another, cultural and media stereotypes can be broken down (Schulenkorf, 2010). In order to achieve such familiarity, this paper 
calls for sport marketers to make a concerted effort towards bridging the gap between the Muslims and the rest of the British population.

Malcolm et al. (2010) point out that there is a relative absence of Muslims from major Western and international sports events. The largest proportion of Muslims living in the UK has an Indian sub-continent origin and cricket plays a special role in most, if not all, of these people's lives (Burdsey, 2006; 2010). In light of this, this paper argues that cricket can play a major role in bringing the Muslim community together with the rest of the British community. As well as being of social benefit, this paper also argues that there are also economic and marketing benefits for cricket management in targeting Muslim spectators.

\section{Sport as a Driver of Social Change}

Many researchers as well as practitioners may argue that sport is apolitical and hence it cannot be expected to perform duties that should be left to the state and the politicians (Malcolm et al., 2010). This view is also supported by economists (e.g. Friedman, 1962; Turner and Marichal, 2000). For instance, the traditional economic view of the firm put forth by Friedman (1962) depicted business as being totally separate from politics. This is a view that is quite popular with many economists as well as businesses themselves and it is especially the case when it comes to sports organisations. This may be because a major motivation for attending and following a sport has been attributed to escape (e.g. Wann and Branscombe, 1993; Trail and James, 2001). Hence, when spectators are trying to 'escape' their daily routines and pressures of daily lives, they would prefer to pursue an activity that is seen as being apolitical. However, the view that businesses and sports organisations need to stay away from issues broadly seen as political is changing as many organisations become engaged with Corporate Social Responsibility (CSR) and Social Marketing becomes more prominent.

In the broader business context, many businesses are now engaging in activities that were once classed as belonging to the purely political domain. This includes initiatives to improve and provide education to help tackle poverty issues, working to 
increase awareness and prevention of the spread of AIDS and deal with many other social ills (e.g. Scherer and Smid, 2000; Fort and Schipani, 2004). Organisations often begin to engage in philanthropic activities as a way to demonstrate to their stakeholders that they care about the society within which they operate. In the era of marketing savvy consumers, businesses are finding it more and more difficult to convince consumers that their CSR activities are genuine and not undertaken merely as yet another marketing tool. Hence, it is important that organisations try to address social issues that are relevant and of significance to the society. This has resulted in more and more business firms becoming important political actors in the global society (Boddewyn and Lundan, 2010).

Following a review of many business organisations' recent CSR activities, Scherer and Palazzo (2011) introduced the concept of 'political CSR'. The authors describe this as:

“....business firms contributing to global regulation and public goods.... where private actors such as corporations and civil society organisations play an active role in the democratic regulation and control of market transactions." (p901)

The above discussion demonstrates that it is becoming acceptable and even expected for business organisations to engage in social activities genuinely and without fear of being accused of political propaganda. With specific regards to sports organisations, there are also many examples and evidence to support the view that, despite its apolitical image, sport and politics have strong links (Guttman, 2003). There are many political events and statements that have been part of the sport arena. These include; two African-American contestents raising their fists in a Black Power salute on the victory podium at the Mexican City Olympics in 1968; United States of America boycotting the Moscow Olympics in the 1980s to protest against the Soviet invasion of Afghanistan; and more recently, Seville Football Club player Frederic Kanoute displaying a shirt on which the word Palestine was written after he scored a goal during a game. These events show that despite the apolitical image of sports, political messages and standpoints have been readily present over the years. 
Cricket, as a sport, has also been subject to political infiltration. Crick (2009) explains that politics and cricket have been linked as far back as 1932 when India gained test status. When the Indians began to beat the English at their own game, it became a political tool to argue that since we are equal (or better) in the sport arena then we should also deserve political equality. Cricket was also used to make a political statement by Britain and other countries against South Africa in the Apartheid era where games with South African cricket team were discontinued. An ongoing and very prominent case of political presence in cricket can be seen in the case of cricket games between India and Pakistan. Crick (2009) documented how cricket has played a key role in politics between India and Pakistan. When the relationship between the two countries have been very hostile, the governments of India and/or Pakistan ban bilateral games between the two nations. On the other hand cricket games have also been used as a tool for trying to mend the relationship between the two countries with the then prime minister of India, Vajpayee, travelling to Pakistan in 2004 to allegedly watch the game of cricket between India and Pakistan but using the opportunity to engage in political discussions with his Pakistani counterpart. In the UK there have been attempts by certain political parties and politicians to use sport and people's support of sport teams as proof of their national identities and loyalties. Lord Tebbit, the former Conservative party chairman and member of parliament, controversially called for what is commonly referred to as the Tebbit test. Lord Tebbit claimed that supporting a cricket team of one's country of origin rather than England (the adopted nation) can be seen as an act of treachery (Wilson and Liu, 2012).

Moving away from the direct involvement of the state in cricket, media have also been claimed to be using cricket to make political statements. McDonald et al. (2010) investigated the British media coverage of and representation of Islam and Muslims in the post 9/11 era. The authors used the media coverage of the death of Pakistani cricket coach Bob Woolmer during the 2007 cricket world cup in Jamaica (a phenomenon known as Woolmergate) to illustrate their arguments. Bob Woolmer's death was shrouded in mystery especially as it occurred the day after Pakistan lost to Ireland and subsequently exited the world cup competition. McDonald et al. (2010) 
looked at 768 articles published in 9 british national daily newspapers and their Sunday couterparts. The authors claimed that due to sport being commonly viewed as apolitical and hence benign, it was used by the media to highlight, and in some cases reaffirm, the British public opinion about Islam, Muslims and Asian men. Due to the suspicious circumstances of Woolmer's death, the Jamaican police announced a murder investigation. McDonald et al. (2010) demonstrated how the speculation in the British press has been about the involvement of one or more of the Pakistani players, fans or bookmakers. In all these cases the coverage has centered around religious and cultural generalisations about Muslims as being irrational, violent, and a static society.

If politicians and the media can exploit the apolitical and benign perception of sport, then it should also be possible for sport managers to use the same qualities of sport (i.e. apolitical and benign) in order to bring about positive change in society. This paper argues that sport has a responsibility towards their local communities and the larger society to drive change within society. Baines et al. (2010), through their investigation of terrorist messages on the internet, concluded that new information technology and social media cites are being used by terrorist organisations such as AlQaeda to tap into the emotions and target British Muslims. Sport marketers can play a key role in negating the emotional pull of terrorist propaganda and channel the emotions of British Muslims, especially the Muslim youth, towards sport. A discussion on how sport can help build community cohesion and create a sense of belonging will be presented later in the paper following a discussion on British Muslim Identity and how it relates to cricket in particular.

\section{British Muslim Identity}

Identity is often described as a '.....condition of being oneself (and not another)' (Kabir, 2010) and 'those things that set you apart from other 'in-group' members and mark you as special or unique' (Samovar et al., 2010:155). In order to feel a sense of belonging and wellbeing, every individual needs to feel comfortable with their sense of self. As a person, we may have many identities including that of a daughter/son, brother/sister, parent, teacher, researcher, and so on. When it comes to collective 
identities, however, there are many debates on whether it is possible to have multiple identities. This discourse is ever present in discussions about identities of ethnic minorities living within a given country or state. In academic literature discussing social identity, the commonly used theory is that of Tajfel and Turner's (1979) Social Identity Theory. Social Identity Theory explores how people identify themselves as belonging to one group (in-group) and different to that of another (out-group). Hence, group identity is about a sense of shared belonging and similarities, and the differences that create the rhetoric of 'us' and 'them' (Kabir, 2010).

The recurrent theme of debates on national identity is often the call for all people from within a nation to have one identity. Yet, social scientists have long accepted that multiple identities can exist within people without it resulting in any socially harmful attitudes or behavior. In the simplest terms, if you can be a parent, daughter or son, husband or wife, colleague, etc. all at the same time, you can also be a Muslim, British, Black, etc. simultaneously. Joseph (2011), whilst discussing the Black Americans from a Caribbean origin, refers to these multiple identities as 'double consciousness'. This is whereby an individual has the sense of knowing one's self as Black and as a national subject.

Within the Islamic context, Muslims living in the West have to reconcile their identity as a Muslim with that of being English, American, French and so on (Monshipouri, 2009). There is often a general misconception by both Muslims and non-Muslims that the Muslim identity conflicts with the identity of being English or any other Western country (Monshipouri, 2009). However, it is mentioned in the Quran that 'had God so willed, He would have made you a single community' (Chapter 5: Verse 48). But, '.....we made you into nations and tribes so that you may know one another' (Chapter 49: Verse 13). Thus, as a Muslim, you accept that there are differences among people in terms of culture and behavior and that you can be from any culture from anywhere in the world whether it be European, Asian or African, and still be a Muslim. The challenge is how you incorporate your multiple identities so that they can co-exist in harmony. Ramadan (2010) explains that this challenge of dealing with differences is the true meaning of the Islamic concept of Jihad. It is 
about 'managing our natural, individual and/or collective contradictions, and seeking peace' (Ramadan, 2010:10).

The ever present debates about immigration into the UK and other European countries constantly return to the idea that immigrants or the community who come to live here are still loyal to their countries of origin. This is often depicted in their support of sport teams. Sociologists and psychologists believe that people's origins provides them with a sense of belonging and when they migrate to other countries, their place of origin creates feelings of nostalgia. As human beings, we try to hold onto our roots because they form part of our identity. Often we create an idealistic view of our origins and it is this idealistic view that we try to hold onto.

...the origin of meaning always seems more ideal or more alive than the meanings we encounter on our path. That is the source of the nostalgia for origins that runs through all traditions and all religions. (Ramadan, 2010: 6)

Joseph (2011), investigating the sport tourism motivations of a Caribbean-Canadian cricket club, found that the team travels to the Caribbean to revisit the past. The author explained that sport tourism offers the diaspora community a chance to engage in nostalgia and revisit the past (in their minds) and feel connected to their roots. Authors have claimed that affiliation with a sport team can reveal an individual or community's integration into the wider society or its separateness from it (Kabir, 2010). Cricket is the major sport in the Indian sub-continent and support for a particular cricket team is taken to be the ultimate test of one's loyalty to their nation. For instance, in India, Muslims are generally viewed as suspected supporters of the Pakistan national cricket team (Bénéi, 2008; Crick, 2009). This creates a great deal of tension within the country especially when the two countries play against each other. Any Muslim supporting the Pakistan cricket team is seen as a traitor and is often subject to violent attacks. In Sri Lanka, the Tamils are often seen as the traitors for choosing to support other nations. Some people within the Tamil community would support any other team playing against Sri Lanka to show their discord with the country. There is however, a general perception that if you are a Tamil, then you support India (Roberts, 2005). This is very similar to the situation of Muslims of a South-east Asian origin in the UK. Their decision to support a national team other 
than England is seen as a sign that they are not integrated into society and their loyalties lie elsewhere.

There is evidence of a discourse amongst the British South-east Asian community with regards to their identities and hence support for the British and English teams. They are more likely to identify themselves as being British rather than English. Burdsey (2006) explains that, amongst the Asian community, being 'English' has negative racial connotations of being 'white'. This rejection of Englishness can often result in their support of international cricket teams. However, interestingly, when it comes to football, British South-east Asians often support England. One explanation for this is that South-east Asian countries (India, Pakistan, and Sri Lanka) are strong forces within the cricketing world but are almost non-existent in the football world. Hence, supporting the Pakistan cricket team, for instance, can show their equality to the English team. Another point of view is the concept of 'situating strategies'. British South-east Asians' support of their national football team (England, Scotland, or Wales) can signal their attachment to what is regarded as 'home'. Whereas supporting India or Pakistan when it comes to cricket, fulfills their need to maintain their links to their 'ancestral homes' (Burdsey, 2006).

\section{Cricket as a Community Cohesion Tool}

As discussed before, the idea of sport being apolitical and hence needing to keep away from any involvement with political ideas or activities no longer holds ground. Many sports organisations are involved with activities to engage Black and ethnic minorities within their local community in order to provide social and personal development to the youth. This is especially the case with many football clubs in the UK. Even with specific reference to cricket, international cricketers defying the ban to play against South Africa was seen as instrumental in changing people's views on apartheid and thereby drawing it to an end.

Sport is also being used more explicitly as a tool to build bridges between communities. For instance, in war-torn Sri Lanka, the divide between Tamils and the Sinhalese is immense. The Asian-German Sports Exchange Programme (AGSEP) has 
been working in Sri Lanka since 2002 to bring communities together with special focus on youth integration projects. The project has used sport as a common denominator that can help bring the youth in the Western and Northern parts of Sri Lanka. AGSEP recognises that sport, and the youth interest in sports, can be a common ground for Tamils, Sinhalese and Muslims to come together. They organise special sport events where young people from Tamil, Sinhalese and Muslim backgrounds come together to compete in various sport activities. They organise special community sport days and even weekends where the families of these young people can come together. Schulenkorf (2010) found that during these AGSEP organised sport events both ethnic and national identities were simultaneously salient. That is to say that people saw themselves as Tamil, Sinhalese, or Muslims but also as being part of the larger Sri Lankan community. These sport events facilitated personalisation amongst people and they were no longer seen as a stereotypical 'other' but as fellow Sri Lankans. Schulenkorf (2010) points out that participants and spectators at these events claimed that the sporting atmosphere enabled them to see each other as similar to themselves and also to see the good in others.

The concept of Social Development is seen to have three aspects; social capital, capacity building and social change (Moscardo, 2007). Many sport organisations in the UK engage in capacity building aspect of social development which focuses on development of particular skills and knowledge to empower communities. Although capacity building is by no means completely achieved and still requires considerable input, sport organisations should also make an effort to build trust between communities (social capital) and community cohesion (social change). Cricket in the UK has come a long way in its attempts to include players from ethnic minority origins. Especially at the county cricket level, the number of Muslim players from a South-east Asian origin has increased considerably over the years. Many county cricket clubs have changed their attitudes and behaviour towards Muslim players. It is no longer uncommon to see British Muslim players practicing their religion in terms of prayers in their dressing rooms and most county clubs provide Halal food options for their players (Burdsey, 2010). Investigating the British Muslim players' experiences in English first class cricket, Burdsey (2010) argues that 'cricket's 
subversive post-colonial potential may, for the time being at least, is limited to the field of play' (p330). Now the cricket management need to take this further and use the potential of cricket as a community cohesion tool that can benefit the community as a whole.

\section{Conclusion}

Community cohesion, especially with regards to the Muslim community in the UK has taken centre stage post 7/7. This paper has shown that sport and especially cricket (due to its large South-east Asian following) can play a key role in bringing communities together. The apolitical nature of sports and the sporting atmosphere can help bring familiarity between Muslims and the wider British community and thereby breaking down the stereotypes. More specifically at the English first class county level, the games can be used as a focal point for local communities to engage in a common activity based on the shared interest of cricket.

From the Muslim point of view, living in harmony with one's neighbours and the wider community is a religious duty.

God does not forbid you, with regard to those who do not fight you for your faith nor drive you out of your homes, from dealing with affection and justice with them: for god loves those who are just. (Al-Quran chapter 60: Verse 8).

Furthermore, cricket games can be used by Muslims to break down some of the negative images and stereotypes held by the wider community.

From the cricket management's point of view, using cricket to actively bring communities together would ensure that they are engaging in an effective and worthwhile corporate social responsibility initiative. Additionally, from marketing perspective, it will help increase the interest in the game and result in increased attendance at the domestic games. At a time when English domestic cricket is attempting to appeal to a wider audience (Kuenzel and Yassim, 2007, 2010), the Muslim community is a segment that they need to be paying more attention to. 
Combining social marketing elements as well as marketing objectives in cricket will ensure that sport acts as a wealth-creator rather than remain as simply a zero-sum game (Wilson and Liu, 2012).

As Kabir (2010) found, despite the stereotypical image of sport (within the Muslim community) being a male domain, young Muslim women are also keen football fans. This raises the possibility of a new segment for the domestic cricket games which the cricket management need to investigate further.

From the perspectives of cricket fans in general, by actively participating and engaging with any efforts by the cricket management to bring communities together, they can become 'citizen diplomats' (Byrne and Keashly, 2000). Cricket citizen diplomats are a crucial part of bringing about social change in the wider community for if they fail to engage then there is little chance of success.

Finally, it is not suggested here that by merely attracting more Muslim spectators to the game, the divisions and prejudices within our society would disappear. It also does not imply that this is a simple and easy task that can be tackled by cricket managers alone. However, cricket provides a common ground where the different parties can meet based on a shared interest. This is especially true in the domestic first class games where national team affiliations do not interfere with the enjoyment of cricket as a sport per se. Cricket can provide a place for people to become familiar with one another and this familiarisation can lead to breaking down of stereotypes and be the starting point to building a positive image of the so called 'other'. This may only provide a starting point, but it is well worth investigating for the benefit of both cricket and our wider society. When the conflicts and differences between the world's Muslim community and the West are dominating our daily lives, this small starting point is an opportunity which we should not ignore. 


\section{References}

Allen, C. (2010) Islamophobia, Surrey: Ashgate Publishing.

Baines, P.R. and O'Shaughnessy, N.J. and Moloney, K. and Richards, B. and Butler, S. and Gill, M. (2010) "The dark side of political marketing: Islamist propaganda, reversal theory and British Muslims," European Journal of Marketing, Vol. 44 No. 3/4, pp. 478-495.

Bénéi, V. (2008) Schooling Passions: Nation, History, and Language in Contemporary Western India, California: Stanford University Press.

Boddewyn, J. J. and Lundan, S. M. (2010) "The internalization of societal institutions" In A.G. Scherer and G. Palazzo (2011) Journal of Management Studies, Vol. 48 No.4, pp.899-931.

Burdsey, D. (2006) "If I ever play football dad, can I play for England or India? British Asians, sport and diasporic national identities," Sociology, Vol. 40 No. 1, pp. 11-28.

Burdsey, D. (2010) "British Muslim experiences in English first-class cricket," International Review for the Sociology of Sport, Vol. 45 No.3, pp. 315-334.

Byrne, S. and Keashly, L. (2000) "Work with ethno-political conflict: A multi-modal approach," In T. Woodhouse and O. Ramsbotham (Eds.), Peacekeeping and Conflict Resolution (pp. 97-120). London: Frank Cass.

Carrington, B. (2008) "Where's the white in the Union Jack?” In M. Perryman (Ed.), Imagined nation: England after Britain (pp. 109-133). London: Lawrence and Wishart.

Chigas, D. (2003) “Track II (Citizen Diplomacy)” In G. Burgess and H. Burgess (Eds.), Beyond Intractability. Boulder, CO: Conflict Research Consortium, University of Colorado, August.

http://www.beyondintractability.org/essay/track2_diplomacy/?nid=1329 accessed on 3/03/2005.

Crick, E. (2009) “Contact sport: Cricket in India-Pakistan relations since 1999” South Asian Survey, Vol. 16 No. 1, pp.59-79.

Ennaji, M. and Sadiqi, F. (2011) "Introduction: Contextualising gender and violence in the Middle East," in Gender and Violence in the Middle East, Oxon: Routledge, pp.1-10.

Esposito, J. and Lalwani, S. (2011) "No, Muslims are not taking over the world," The Guardian, Friday $11^{\text {th }}$ February http://www.guardian.co.uk/commentisfree/belief/2011/feb/11/islam-population accessed on 22/06/2012. 
Fort, T. L. and Schipani, C. A. (2004) The Role of Business in Fostering Peaceful Societies, Cambridge: Cambridge University Press.

Friedman, M. (1962) Capitalism and Freedom, Chicago, IL: University of Chicago Press.

Guttmann, A. (2003) "Sport, politics and the engaged historian," Journal of Contemporary History, Vol. 38 No. 3, pp363-75.

Joseph, J. (2011) “A diaspora approach to sport tourism," Journal of Sport and Social Issues, Vol. 35 No.2, pp. 146-167.

Kabir, N.A. (2010) Young British Muslims: Identity, Culture, Politics, and the Media, Edinburgh University Press: Edinburgh.

Kuenzel, S. and Yassim, M. (2007) "The effect of joy on the behaviour of cricket spectators: the mediating role of satisfaction," Managing Leisure, Vol.12, pp. 43-57.

Kuenzel, S. and Yassim, M. (2010) "Game experience: An analysis of English and Welsh domestic cricket spectators," International Journal of Nonprofit and Voluntary Sector Marketing, Vol.15, pp. 52-66.

Malcolm, D. and Bairner, A. and Curry, G. (2010) "Woolmergate: Cricket and the representation of Islam and Muslims in the British Press," Journal of Sport and Social Issues, Vol. 34 No. 2, pp215-235.

Monshipouri, M. (2009) Muslims in Global Politics: Identities, Interests and Human Rights, Philadelphia: University of Pennsylvania Press.

Moscardo, G. (2007) "Analyzing the role of festivals and events in regional development," Event Management, Vol. 11 No. 1-2, pp. 23-32.

Ramadan, T. (2010) The Quest for Meaning: Developing a Philosophy of Pluralism, London: Penguin Books.

Roberts, M. (2005) "Sri Lanka: The power of cricket and the power in cricket," in Wagg, S. (Ed) Cricket and National Identity in Post-colonial Age: Following On, Oxon: Routledge, pp.132-158.

Salzman, M. (2007) “Engaging Muslim consumers,” Brand Strategy, October.

Samovar, L.A. and Porter, R.E. and McDonald, E.R. (2010) Communication Between Cultures, $\left(7^{\text {th }} \mathrm{Ed}\right)$ Boston: Wadsworth.

Sandikczi, O. and Rice, G. (2011) "Islamic marketing: An introduction and overview," in Handbook of Islamic Marketing, Cheltenham: Edward Elgar pp.1-16. 
Scherer, A. G. and Smid, M. (2000) "The downward spiral and the U.S. model principles: Why MNEs should take responsibility for the improvement of world-wide social and environmental conditions," Management International Review, Vol. 40, 351-71.

Scherer, A. G. and Palazzo, G. (2011) "The new political role of business in a globalised world: A review of a new perspective on CSR and its implications for the firms, governance, and democracy," Journal of Management Studies, Vol. 48 No.4, pp.899-931.

Schulenkorf, N. (2010) "Sport events and ethnic reconciliation: Attempting to create social change between Sinhalese, Tamil, and Muslim sportspeople in war-torn Sri Lanka," International Review for the Sociology of Sport, Vol. 45 No. 3, pp. 273-294.

Tajfel, H. and Turner, J. (1979) "An integrative theory of intergroup conflict," In W.G. Austin and S. Worchels (Eds.) The social psychology of intergroup relations. (pp. 33-48), Monteray, CA: Brooks/Cole.

Temporal, P. (2011) Islamic Branding and Marketing: Creating a Global Islamic Business, Singapore: John Wiley.

Trail, G. and James, J. (2001) "The motivation scale for sport consumption: A comparison of psychometric properties with other sport motivation scales," Journal of Sport Behaviour, Vol. 24 No. 1, pp. 108-127.

Turner, R.S. and Marichal, J.F. (2000) "Exploring politics on the sports page," in Rich, W.C. (Ed) The Economics and Politics of Sports Facilities, Westports: Quorum Books, pp.189-202.

Wann, D. and Branscombe, N. (1993) "Sport fans: Meaning of the degree of identification with their team," International Journal of Sport Psychology, Vol. 24, pp. 1-17.

Whittaker, B. (2002) Islam and the British press after September 11. http://www.albab.com/media/articles /bw020620.htm accessed on 14/10/2008.

Wilson, J.A.J. and Liu, J. (2012) "Surrogate brands - the pull to adopt an 'other' nation via sport merchandise," International Journal of Sport Management and Marketing, Vol. 11, pp. 172-192. 
